\title{
Enhance Growth and Flower Quality of Chrysanthemum indicum L. with Application of Plant Growth Retardants
}

\author{
Endre Kentelky ${ }^{1} \mathbb{D}$, Zsolt Szekely-Varga ${ }^{1, * \mathbb{D}}$, János Bálint ${ }^{1}$ and Adalbert Balog ${ }^{1,2, *(\mathbb{D})}$ \\ 1 Department of Horticulture, Faculty of Technical and Human Sciences, \\ Sapientia Hungarian University of Transylvania, Sighișoarei 1C, 540485 Târgu Mureș, Romania; \\ kentelky@ms.sapientia.ro (E.K.); balintjanos@ms.sapientia.ro (J.B.) \\ 2 Doctoral School of Biology and Sport Science, Faculty of Natural Science, University of Pécs, \\ 7622 Pécs, Hungary \\ * Correspondence: szekelyvarga.zsolt@gmail.com (Z.S.-V.); adalbert.balog@ms.sapientia.ro (A.B.)
}

check for updates

Citation: Kentelky, E.; Szekely-Varga, Z.; Bálint, J.; Balog, A. Enhance Growth and Flower Quality of Chrysanthemum indicum $\mathrm{L}$. with Application of Plant Growth Retardants. Horticulturae 2021, 7, 532 https://doi.org/10.3390/ horticulturae7120532

Academic Editors: Mohammad Zahirul Islam and Anastasios Darras

Received: 23 September 2021 Accepted: 24 November 2021 Published: 1 December 2021

Publisher's Note: MDPI stays neutral with regard to jurisdictional claims in published maps and institutional affiliations.

Copyright: (c) 2021 by the authors. Licensee MDPI, Basel, Switzerland. This article is an open access article distributed under the terms and conditions of the Creative Commons Attribution (CC BY) license (https:// creativecommons.org/licenses/by/ $4.0 /)$.

\begin{abstract}
Ornamental plants are cultivated worldwide. Chrysanthemum is classified as one of the most important cut and potted flowers in most of the countries. The consumer's expectation is to find small-compact, and full of inflorescences plants. To meet these demands, growers are tending to use plant growth retardants. Three Chrysanthemum indicum L. varieties ('Smola White', 'Arber' and 'Vienna White') were assessed by using four plant growth regulators (PP-Bumper 250 EC; CC-Stabilan SL; MP-Medax Top SC; and PD-Toprex SC). Results indicate that treated plants show significant decrease in the assessed parameters, although in some cases growth could be a varietydependent factor. It can also be concluded that retardants inhibit chrysanthemum growth. PD treatments greatly inhibited the growth of the plant, and also had a negative effect on inflorescences. In conclusion, the present work strengthens the possibility of using retardants as plant growth inhibitors in Chrysanthemum cultivation.
\end{abstract}

Keywords: inflorescences; inhibition; internodes; retardants; varieties

\section{Introduction}

Flower cultivation is widely spread through the whole world and represents a significant economic income. The ornamental plant industry embraces the cultivation and trade of cut greens and flowers, potted and bedding flowers, and house-plants [1,2].

Ornamental plants are cultivated in many regions around the world. Europe being an important production and consumption center for floriculture. Here, the main producer countries are the Netherlands, Germany, Belgium, France, Spain [3-5], and also Romania with smaller areas of ornamental plant production. Producers from smaller countries, in order to cope with the big flower industries, are more less forced to use fertilizers, pesticides, growth retardants, to produce a higher flower quality to lure the consumers with a better product.

Chrysanthemums are one of the most important cut and potted flowers on the worldwide market [6]. According to Van Huylenbroeck [1] potted chrysanthemum occupies the seventh place in the number of turnovers on the Dutch market.

Chrysanthemum indicum L. is a member of the Asteraceae family; a perennial plant originating from Asia [6-8]. Many chrysanthemum species are appreciated for their medicinal use (anti-inflammatory, humoral and cellular immunomodulatory, pemphigus, scrofula, swelling and pain) [9-11]. The plant's extract was also efficient for treating age-associated disorders (brain and liver injury, or obesity) in mice [12,13]; however, most of them are used for ornamental purposes. In some European countries (Hungary, Romania, Austria) chrysanthemums are known and used mostly as "All Souls' Day" flowers; nevertheless, in recent years these plants have also started to be used for floral bouquets or arrangements. Its usage as cut flowers is due to the wide popularity of the 
large number of varieties with different size, shape of the inflorescences, color, and for the long lasting and excellent quality of the blooms as cut flowers [14,15].

Yet, potted chrysanthemums are preferred to have a more compact, smaller growth in height, this additionally can add a better, dense look and a higher value. There are some new varieties which can meet these consumer expectations, however additional effects can be achieved using different growth regulators. Plant growth regulators can influence the yield and the quality of the blooms, foliage and production; several of them are widely used for many ornamental plants, and their effect has been demonstrated in previous research [16-18]. Plant development can also be controlled by plant growth retardants, which can be applied to almost all horticultural crops, to reduce the longitudinal growth without affecting plant productivity $[19,20]$. Plant growth retardants consist of chemical antagonists to gibberellins, the hormone responsible for plant growth [21,22].

Paclobutrazol is a widely used growth regulator in agricultural crops [23]. It is an internode extension and cell elongation inhibitor which inhibit plant growth by influencing gibberellins biosynthesis. Cell elongation is stimulated by gibberellins, when the production is inhibited, the new cells stop the elongate process [24]. The result of paclobutrazol could be noticed by a more compact growth plant, with the same number of leaves and internodes on shoots, but more compressed into a shorter length [25]. Additionally, paclobutrazol could increase number of inflorescences, accelerate the inflorescence opening and reduce plant height significantly [26].

Mepiquat chloride is a growth regulator widely applied in different crop production; it improves the allocation of biomass to a reproductive structure and by that leaf area and node length is reduced [27,28]. Mepiquat chloride inhibits gibberellins biosynthesis, has a high potential to restrict cell elongation, and so it is reducing the growth of plants $[29,30]$. However, it was reported that mepiquat chloride could also increase resistance to water deficit [31,32].

Propiconazole is a systematic azole fungicide [33]; beside the previously mentioned effect, propiconazole targets the brassinosteriod biosynthesis pathway in plants [34]. Brassinosteroids is an important group of phytohormones that has multiple functions in plants such as growth and development [35]. Gibberellins and brassinosteroids work together to regulate plant growth, and through affecting these parameters plants show dwarf phenotype [36].

Chlormequat chloride blocks multiple biosynthesis pathways of gibberellins [37] and is used successfully in floriculture as a plant growth retardant. It is easily absorbed by leaves and roots of plants and works efficiently [38], it was found to inhibit stem elongation, increases stem thickness and controls the flowering appearance [39].

The aim of our research was to investigate the effect of four plant growth retardants (Toprex SC, Medax Top SC, Bumper 250 EC and Stabilan SL) mostly used in Romania in the potted Chrysanthemum cultivation through comparison of the selected plant parameters. The main role is to fulfill consumer expectations towards a compact, affluent, dwarf and more aesthetically pleasing potted chrysanthemums. The selected Chrysanthemum varieties were 'Smola White', 'Arber' and 'Vienna White'. Growth parameters as the number of leaves, the width and length of the leaves, the distance between internodes, shoots number and length, pedicel elongation were evaluated together with bud and inflorescence diameters.

\section{Materials and Methods}

\subsection{Experimental Set-Up and Plant Material}

The experiment was conducted under greenhouse conditions between July and November 2018 at the Sapientia Hungarian University of Transylvania, Târgu Mureș. The humidity and the temperature were measured using Testo $175 \mathrm{H} 1$ (Testo Romania, ClujNapoca, Romania), the average temperature was between 22 and $28^{\circ} \mathrm{C}$ and the relative humidity average $70-90 \%$ (Figure 1). 
120

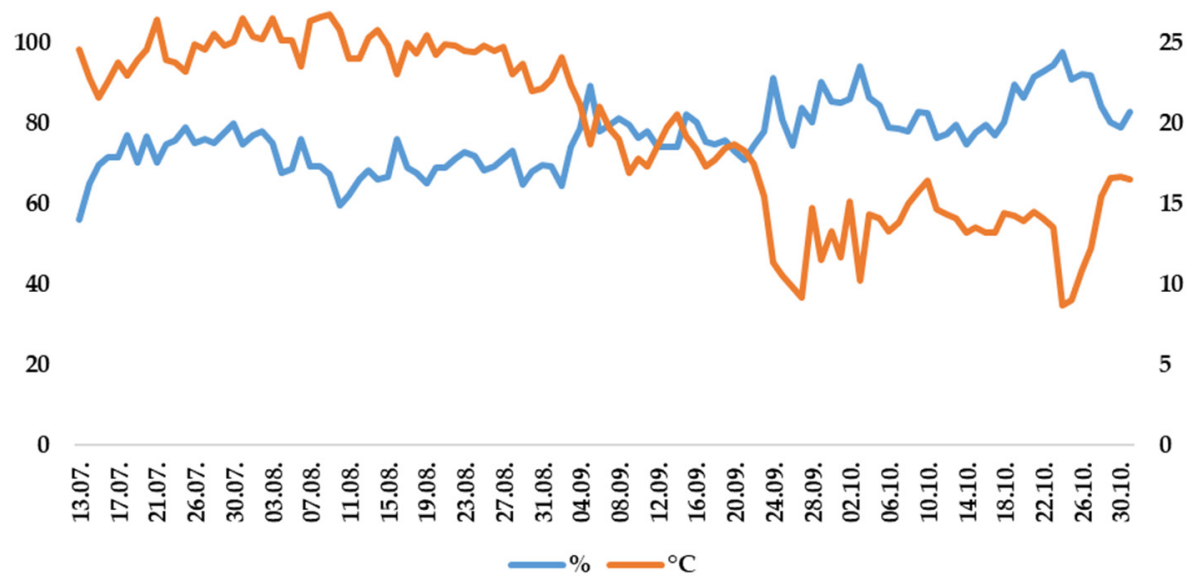

Figure 1. Humidity (\%) and temperature $\left({ }^{\circ} \mathrm{C}\right)$ during the greenhouse experiment (July-November 2018).

The substrate used in experiments was Hawita UNI 20 II (Beppler, Arcuș, Sfântu Gheorghe, Romania) peat. The $\mathrm{pH}$ of the substrate was 5.5-6.5, the granulation 5-25 mm, and N:P:K content of 14:16:18. The experiment was designed in RCBD (Randomized Complete Block Design).

Morphological description of the selected Chrysanthemum varieties were the followings:

- 'Smola White': medium-compact growing potted chrysanthemum with an eight-week response time, producing $11 \mathrm{~cm}$ (diameter) filled, white decorative inflorescences, resistant to white rust and to thrips.

- 'Arber': medium-compact growing potted variety with greenish-white, ball type inflorescences, $13 \mathrm{~cm}$ in diameter, with response time of nine weeks.

- 'Vienna White': middle-compact growing, mostly can be found as cut flower, but with application of retardants could be used also as potted chrysanthemum, response time nine weeks, producing ball form type inflorescences with a diameter of $15 \mathrm{~cm}$.

The rotted plant material was obtained at 7-8 leaf stage from the Brandkamp Company (Isselburg-Anholt, Germany). The 150 cuttings per variety (total of 450 cuttings) were planted in $14 \mathrm{~cm}$ pots in five/row, each row containing 10 chrysanthemums per variety in 3 replications.

The Chrysanthemum cuttings were planted in pots on 13 July 2018; during the growing season, a single pinch back was done on 27 July 2018. The one-time pinch back in the case of the big flower potted Chrysanthemum results in 2-3 new shoots. Additionally, for this type of Chrysanthemums it is essential to remove the side buds around the main bud and the axillary shoots to achieve a quality product, this was done on 17 September. All three selected Chrysanthemums were between 9 and 9.5 flowering induction period, so these varieties are suitable for "All Souls' Days" which is their main purpose for cultivation in Romania. Under normal conditions the short daylight periods in Romania start from mid-September, therefore artificial shading/darkening were applied from 19 August until 16 September, to induce uniform/unvaried flowering. During the experiment, plants were watered directly through soil with drip irrigation system; the dripping mushroom used in the experiment was Netafim PCJ-CNL (Netafim, Tel Aviv, Israel). The plants were fertilized 3-4 times a week. The frequency of the fertilization was determined by the external environmental conditions (temperature and humidity). During the whole growing period, Plantaaktiv (Hauert HBG Dünger, Grossaffoltern, Switzerland) was used, a water-soluble fertilizer, which every two weeks was supplemented with Mikromix (Blondy, Târgu Mures, Romania) liquid nutrition. After the Chrysanthemums were potted, $0.1 \%$ phosphorus (Plantaaktiv Starter) was added to the irrigation water two times. During the vegetation period (23 July-4 September) $0.1 \%$ nitrogen (Plantaaktiv Red) nutrient solution was added through the irrigation water. At the beginning of the generative phase (5-11 September) 
phosphorus nutrient was added two times, because it is an important element in the flowering induction process, from 20 September $0.1 \%$ potassium (Plantaaktiv Blue) was added, to promote the inflorescence development. Calcium nitrate at a concentration of $0.1 \%$ was applied two times through irrigation water during the growing season, after pinching and budding of the plants.

\subsection{Retardants Application}

The growth regulators were selected because of their availability to chrysanthemum growers to be approved for use, and because they were also used in previous studies for other plants, or were recommended [40-43] by Chrysanthemum growers (Beppler, Szigetszentmiklós, Hungary). In the experiment five different treatments were used: Control (plants were sprayed with clean water, on the same date when to the other treatments were applied), PD-Toprex SC (Adama, Ilfov, Romania), MP-Medax Top SC (BASF SRL, Bucharest, Romania), PP-Bumper 250 EC (Adama, Ilfov, Romania) and CC-Stabilan SL (Nufarm, Bucharest, Romania).

A combination of $250 \mathrm{~g} \mathrm{~L}^{-1}$ difenoconazole $+125 \mathrm{~g} \mathrm{~L}^{-1}$ paclobutrazol (PD) was used at a concentration of $0.05 \%$. Regarding the MP, a combination of $300 \mathrm{~g} \mathrm{~L}^{-1}$ mepiquat chloride $+50 \mathrm{~g} \mathrm{~L}^{-1}$ prohexadione-calcium at a concentration of $0.25 \%$; and $250 \mathrm{~g} \mathrm{~L}^{-1}$ propiconazole (PP) was used at a concentration of $0.10 \%$. Respectively, at the CC, $400 \mathrm{~g}$ $\mathrm{L}^{-1}$ of chlormequat chloride was sprayed at a concentration of $0.3 \%$. Additionally, for PD, $\mathrm{MP}$ and PP treatment spraying were used. The application of the treatments was done with a hand sprayer, equipped with Lechler FD 15 POM (Farmcenter, Gödöllö, Hungary) nozzle pressure range between 1.5-4 bars. After each application of treatment, the hand sprayer was well washed to not mix the retardants. First spraying treatment was applied on 3 August 2018, the second on 13 August 2018, followed by the third in 27 August 2018 and the last on 11 September 2018.

\subsection{Measurements and Treatments}

During the experiment, five measurements on 150 Chrysanthemum plants per variety, in a total of 450 cuttings at four treatments were performed.

The $\mathrm{pH}$ and electrical conductivity (EC) of the peat were measured at the beginning and at the end of the experiment. These parameters were recorded using Stelzner $\mathrm{pH}$ AGRAR 2000 (Pronova, Berlin, Germany) and PET 2000 digital meters (Akytec, Berlin, Germany).

The first measurement was made three weeks after the plants were planted in the pots and one week after the first pinching, when the leaves of the new shoots were already measurable. The following parameters were measured and recorded: the number of leaves, width and length of mature and new leaves, distance between the internodes, shoot number and length.

The second measurement was performed seventeen days after the first treatment and seven days after the second treatment (20 August 2018) and the third, nineteen days (15 September 2018) after the third treatment. The following parameters were assessed: number of leaves, width and length of mature and new leaves, distance between the first, second and third internodes, shoot number and length.

The fourth measurement was made nineteen days (30 September 2018) after the last treatment. Number of leaves, width and length of mature and new leaves, distance between the first, second and third internodes, shoot number and length, bud diameter were assessed. The fifth measurement was performed twenty days after the fourth also assessing the pedicel elongation and the inflorescence diameter.

\subsection{Statistical Analysis}

Firstly, all data were tested for normality of errors and homogeneity of variance. As all data were normally distributed, ANOVA followed by Tukey test was used to compare variances. The significance of the differences between the treatments was tested by applying 
two-way ANOVA, at a confidence level of $95 \%$. When the ANOVA null hypothesis was rejected, Tukey's Post hoc test was carried out to establish the statistically significant differences at $p<0.05$.

\section{Results}

\subsection{The $p H$ and $E C$ of the Peat}

At the beginning of the experiment, the substrate in all pots did not show any significant differences in $\mathrm{pH}$ or EC (electrical conductivity), varying between the average values of $5.60(\mathrm{SD}=0.001)$ and $0.50(\mathrm{SD}=0.003)$. As it was expected, after the treatments, these two parameters showed significant differences from the initial values. However, the levels were almost identical for the five treatments (Control, PP, CC, MP, PD). Comparing the treatments to the control, small differences were detected at the PD (Toprex SC), MP (Medax Top SC) in both levels of $\mathrm{pH}$ and peat EC (Figure 2).

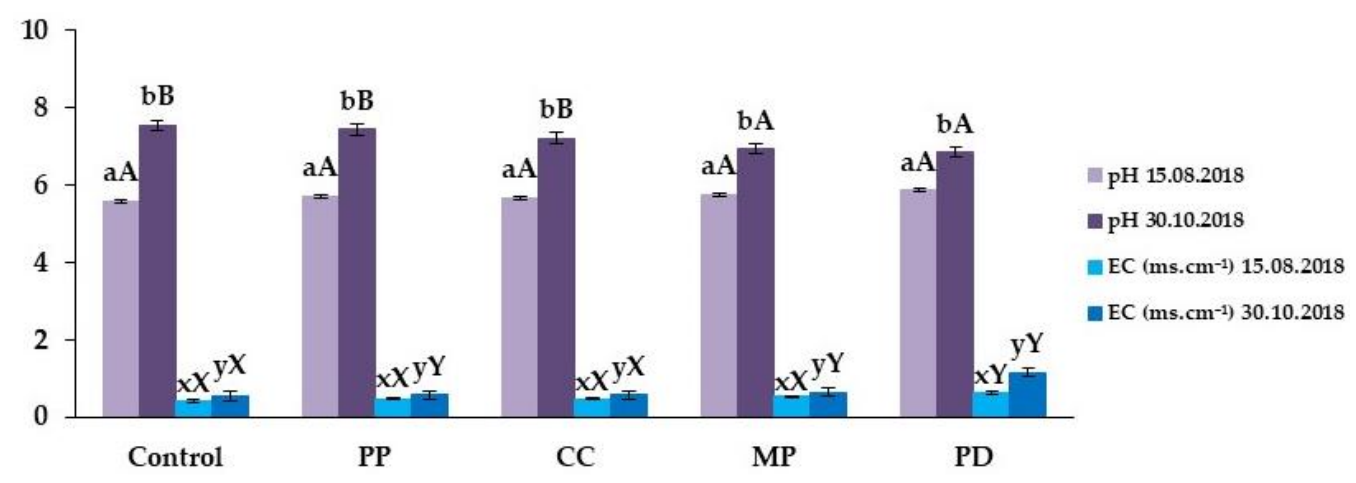

Figure 2. Peat $\mathrm{pH}$ and $\mathrm{EC}$ (electrical conductivity) values at the beginning and at the end of the experiment, under the effect of retardant treatments (PP-Bumper 250 EC; CC-Stabilan SL; MP-Medax Top SC; PD-Toprex SC;). Bars represent the means \pm SE $(n=30)$. Different lowercase letters above the bars indicate significant differences between the measurements at the start (15 August 2018) and the end (30 August 2018) of the experiment, and different uppercase letters indicate the significant differences between the treatments, according to Tukey test $(\alpha=0.05)$.

\subsection{Leaves Number Influenced by the Retardants}

According to the results, retardants influenced the number of leaves appearance in a positive way for all varieties. A small decrease in leaves numbers was reported for PD treatment and for all three varieties. On the other hand, the three retardants (MP, PP, CC) increased the number of leaves appearance for each Chrysanthemum variety.

At 'Smola White' variety the average leaf amount was significantly improved using PP (123.33), CC (136.33) and MP (150) treatments compared to control (93.33). PD treatment negatively influenced the chrysanthemums' number of leaves. Additionally, the number of leaves at 'Arber' was inhibited by PD (61.67) treatment, and no significant differences were observed compared with the other three treatments and with untreated plants (84.33). A greater increase was observed at plants under MP (94.67) treatments and slight increases at PP and CC treatments were detected compared to control. Significant differences were reported between the 'Smola White' and the other two varieties in number of leaves under PP, CC, and MP treatments(Figure 3). 


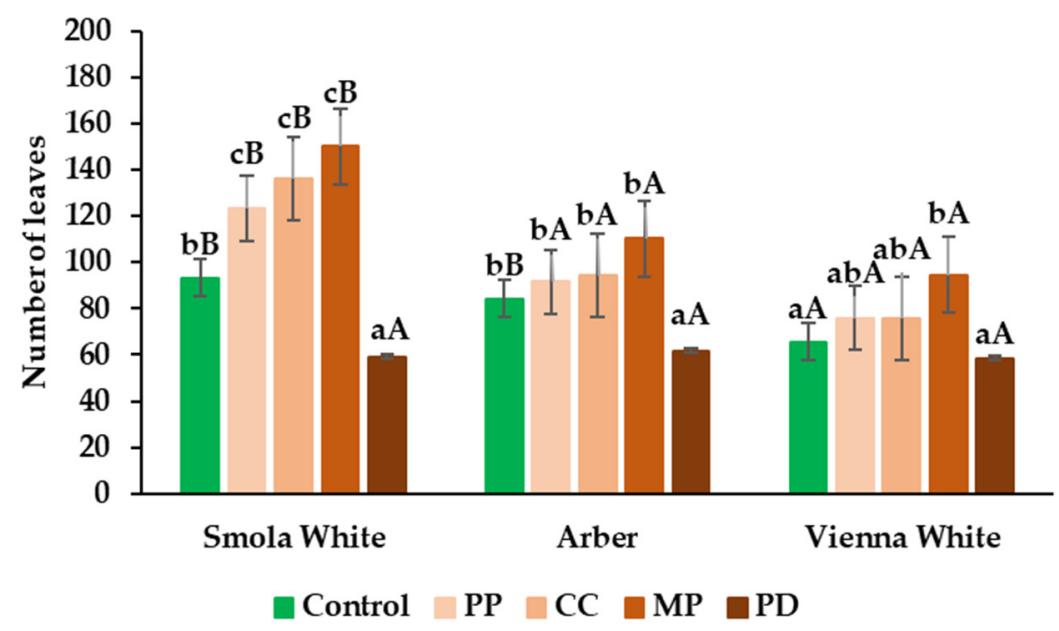

Figure 3. Effect of plant growth retardants on number of leaves parameters in Chrysanthemum indicum L. varieties: 'Smola White', 'Arber' and 'Vienna White'. Plants number of leaves under control conditions, in the presence of the indicated plant growth retardant: PP-Bumper $250 \mathrm{EC}$; CC-Stabilan SL; MP-Medax Top SC; PD-Toprex SC. Bars represent the means \pm SE $(n=30)$. Different lowercase letters above the bars indicate significant differences between the treatments, and different uppercase letters indicate the significant differences between the varieties, according to Tukey test $(\alpha=0.05)$.

\subsection{Length and Width of Leaves under the Effect of Retardants}

The inhibition of the retardants on the length of the mature leaves was observed at PD treatment ('Smola White'-4.96 cm, 'Arber'-6.52 cm, and 'ViennaWhite'-7.87 cm) (Figure 4a). The 'Arber' variety leaves length decreased under the retardant treatments at PP $(5.73 \mathrm{~cm}), \mathrm{CC}(4.24 \mathrm{~cm})$ and PD $(2.82 \mathrm{~cm})$ compared to the control $(5.73 \mathrm{~cm})$. On the other hand, 'Vienna White' recorded inhibition of leaf length at PD treatments where differences were approximatively $2 \mathrm{~cm}$ smaller than control. 'Smola White' new leaves length was significantly smaller than for the other two varieties, however on the opposite side PD treatment increased the length of the leaves. Additionally, the highest decrease was observed in all three varieties under the Toprex SC (PD) treatment (Figure 4b).

Considering the width of the mature Chrysanthemum leaves, no significant differences were reported during the experiment in any of the varieties, although among the varieties, increases at 'Arber' and 'Vienna White' compared to the 'Smola White' were observed (Figure 4c). The new leaves' width decreased under the retardant treatments at 'Smola White' (Figure 4d). Inhibition of width was only observed at PD, while at 'Vienna White' an increase was reported at MP treatments compared to control. Significant differences between the varieties were observed at 'Smola White' and 'Arber' where width of the new leaves greatly increased at all treatments.

\subsection{Distance between the Internodes under the Effect of Retardants}

Retardant treatments decreased growth of all three internodes measured, the highest inhibition was observed at PD (Figure 5). When comparing the varieties, significant changes were determined at 'Vienna White' treated with PP, and CC, where first internodes length was higher than the other two. Yet 'Smola White' first internode length under PD treatment was significantly higher comparing with the other varieties (Figure 5a). 


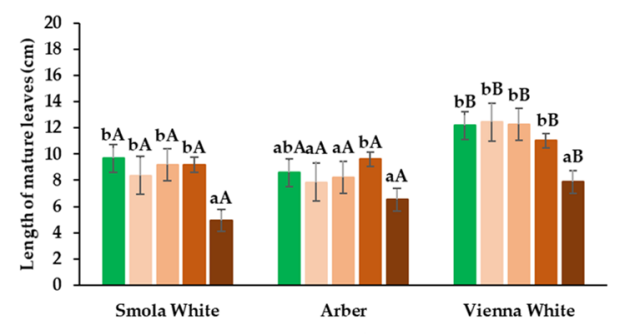

(a)

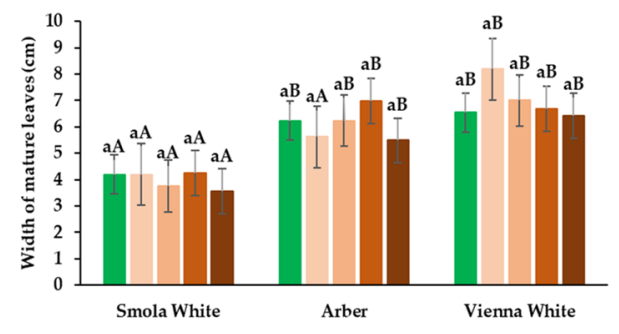

(c)

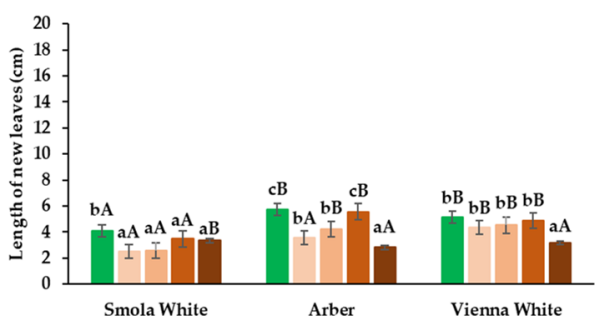

(b)

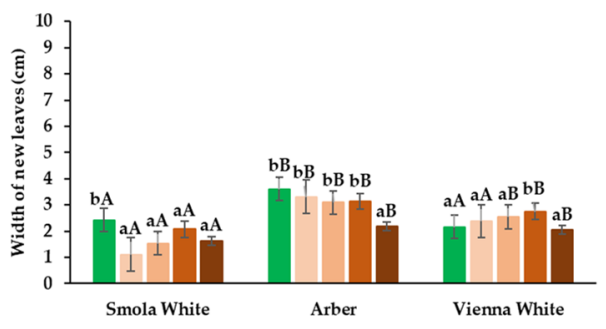

(d)

$\square$ Control $\backsim \mathrm{PP} \backsim \mathrm{CC} \backsim \mathrm{MP} \backsim \mathrm{PD}$

Figure 4. Effect of plant growth retardants on length of mature leaves (a), length of new leaves (b), width of mature leaves (c), and width of new leaves (d) parameters in Chrysanthemum indicum L. varieties: 'Smola White', 'Arber' and 'Vienna White'. Plants under control conditions, in the presence of the indicated plant growth retardant: PP-Bumper 250 EC; CC-Stabilan SL; MP-Medax Top SC; PD-Toprex SC. Bars represent the means \pm SE $(n=30)$. Different lowercase letters above the bars indicate significant differences between the treatments, and different uppercase letters indicate the significant differences between the varieties, according to Tukey test $(\alpha=0.05)$.

Retardants also influenced the growth of the second internodes; the highest decrease was reported at PD treatment (Figure 5b). 'Arber' and 'Vienna White' had a higher increase in the second internodes than the 'Smola White' under control and PP. Similar data were determined at the third internodes measurements; almost all treatments affected the internodes' length (Figure $5 \mathrm{c}$ ).

\subsection{Chrysanthemum Shoots under the Effect of Retardants}

Length of the shoots in most cases was influenced by the plant growth retardants; however, significant increases were observed at the PD retardant. In the case of 'Smola White' inhibition of shoot length was detected in all treatments (PP-39.95 cm, CC-34.9 cm, MP-29.94 cm, and PD-7.86 cm). At 'Arber' significant differences were determined only at PD treatments $(27.47 \mathrm{~cm})$. At 'Vienna White' CC, MP and PD inhibited the length, no significant differences were observed at PP compared to control (Figures 6a and 7). The shoot lengths at 'Smola White' and 'Arber' were significantly smaller than for 'Vienna White' variety. 


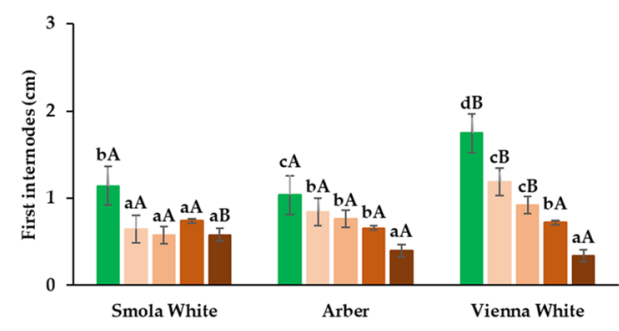

(a)

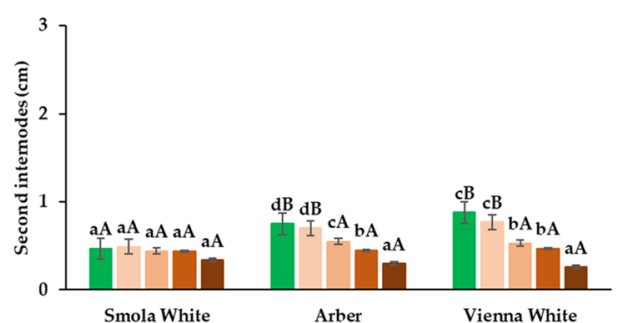

(b)

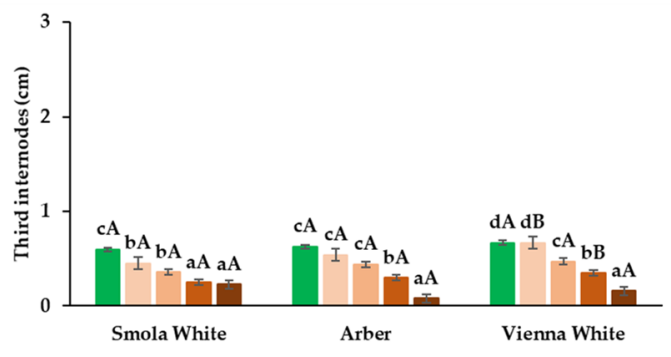

(c)

$\square$ Control $\square \mathrm{PP} \backsim \mathrm{CC} \square \mathrm{MP} \square \mathrm{PD}$

Figure 5. Effect of plant growth retardants on the first (a), second (b), and third (c) internodes in Chrysanthemum indicum L. varieties: 'Smola White', 'Arber' and 'Vienna White'. Plants under control conditions, in the presence of the indicated plant growth retardant: PP-Bumper 250 EC; CC-Stabilan SL; MP-Medax Top SC; PD-Toprex SC. Bars represent the means \pm SE $(n=30)$. Different lowercase letters above the bars indicate significant differences between the treatments, and different uppercase letters indicate the significant differences between the varieties, according to Tukey test $(\alpha=0.05)$.

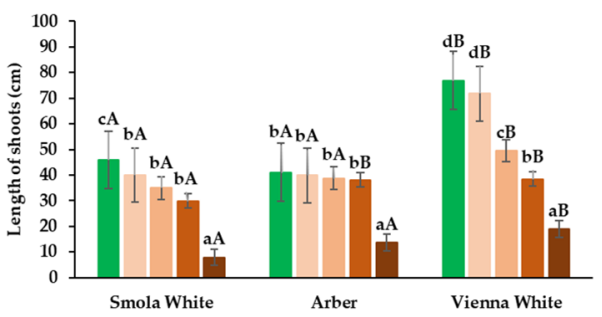

(a)

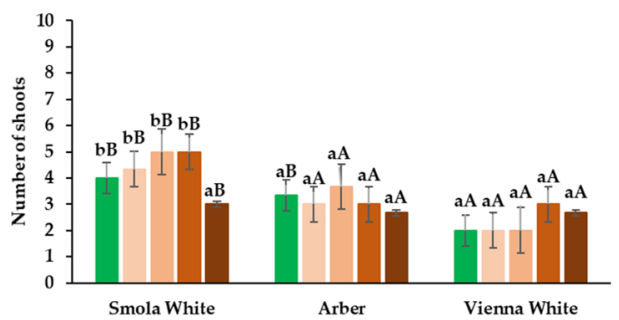

(b)

$\square$ Control $\square \mathrm{PP} \square \mathrm{CC} \square \mathrm{MP} \square \mathrm{PD}$

Figure 6. Effect of plant growth retardants on length of the shoots (a) and number of the shoots (b) in Chrysanthemum indicum L. varieties: 'Smola White', 'Arber' and 'Vienna White'. Plants under control conditions, in the presence of the indicated plant growth retardant: PP-Bumper 250 EC; CC-Stabilan SL; MP-Medax Top SC; PD-Toprex SC.; Bars represent the means \pm SE $(n=30)$. Different lowercase letters above the bars indicate significant differences between the treatments, and different uppercase letters indicate the significant differences between the varieties, according to Tukey test $(\alpha=0.05)$.

Altogether it can be determined that the treatments did not influence the number of shoots of the assessed chrysanthemum varieties, only a small decrease was reported at the 'Smola White' under the PD retardant. The largest shoot number was recorded at the 'Smola White', the average shoot number being four (Figure 6b). 


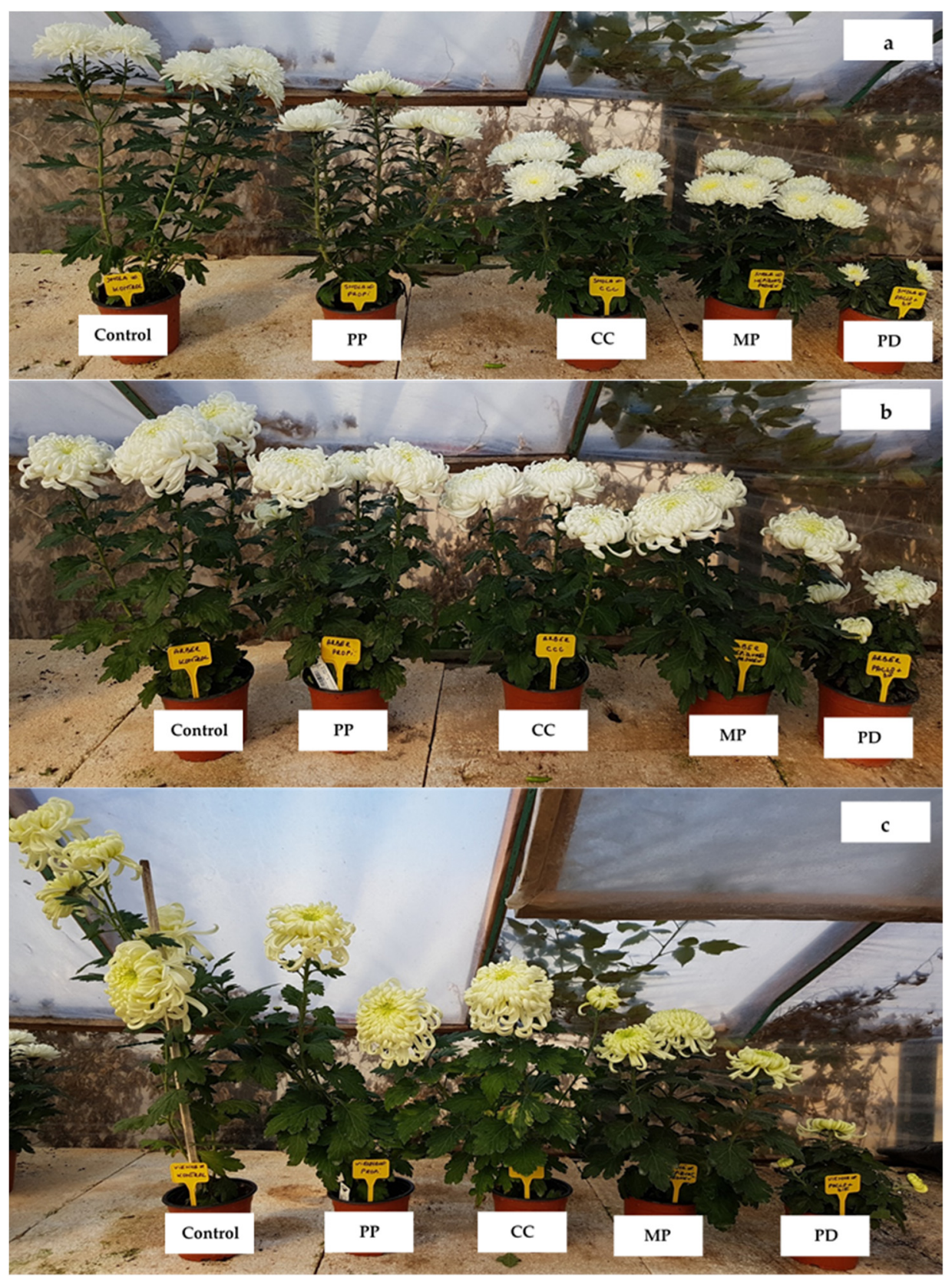

Figure 7. Effect of plant growth retardants on Chrysanthemum indicum L. varieties: 'Smola White' (a), 'Arber' (b) and 'Vienna White' (c). Plants under control conditions, in the presence of the indicated plant growth retardant: PP-Bumper 250 EC; CC-Stabilan SL; MP-Medax Top SC; PD-Toprex SC.

\subsection{Inflorescences}

Plant growth retardants induced pedicel elongation; the highest increase was recorded using PD treatment at 'Arber' and 'Vienna White' (Figure 8a), considering 'Smola White' retardants inhibited the pedicel elongation with $\sim 1 \mathrm{~cm}$, compared to control. 'Arber' presented the smallest pedicel at PD; however, PP, CC, and MP treatments also slowly inhibited the elongation. The difference between PD and untreated plants was $3.49 \mathrm{~cm}$. The highest inhibition of pedicel was reported using PD at 'Vienna White'. The results indicate that the pedicel elongation was variety- and treatment-dependent; the strongest decrease in pedicel elongation was observed at the 'Smola White'. 


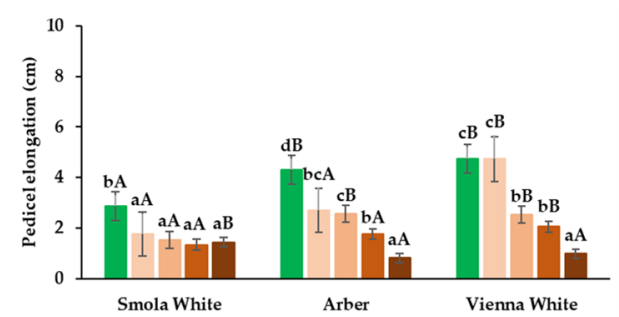

(a)

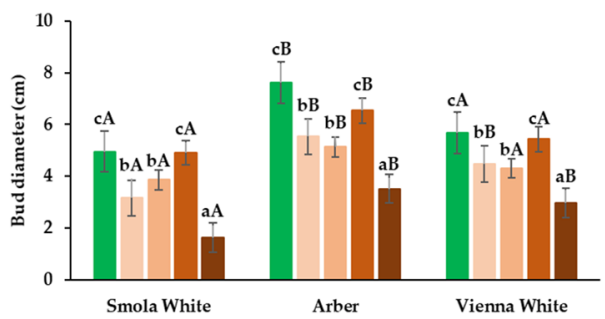

(b)

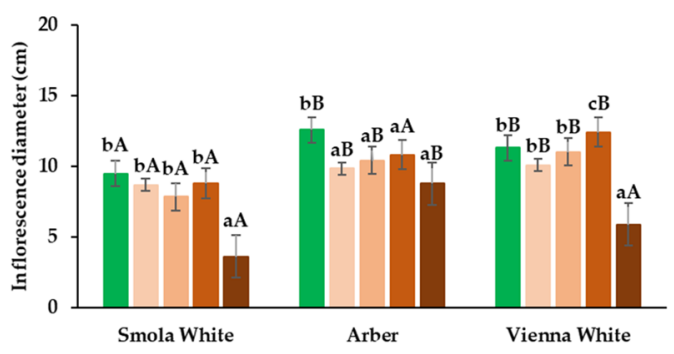

(c)

$\square$ Control $\square \mathrm{PP} \quad \mathrm{CC} \square \mathrm{MP} \square \mathrm{PD}$

Figure 8. Effect of plant growth retardants on pedicel elongation (a), bud diameter (b), and inflorescence diameter (c) in Chrysanthemum indicum L. varieties: 'Smola White', 'Arber' and 'Vienna White'. Plants under control conditions, in the presence of the indicated plant growth retardant: PP-Bumper 250 EC; CC-Stabilan SL; MP-Medax Top SC; PD-Toprex SC. Bars represent the means \pm SE $(n=30)$. Different lowercase letters above the bars indicate significant differences between the treatments, and different uppercase letters indicate the significant differences between the varieties, according to Tukey test $(\alpha=0.05)$.

Bud diameters were significantly influenced (decreased) in all three varieties of Chrysanthemum, under the PD, PP and CC treatments (Figure 8b). Bud diameter in all three varieties was highly inhibited by PD with $\sim 2 \mathrm{~cm}$, compared to control. PP and CC treatments inhibited bud diameter but not in such a drastic way as for the other treatments. Significant inhibition was determined between 'Smola White' and 'Arber' in all tested retardants. 'Vienna White' bud diameter was significantly increased under PP and PD retardants compared to 'Smola White'.

Results also indicate that retardants could influence the inflorescence diameter; a strong decrease was determined at plants under PD treatments in all three varieties (Figure 8c). The 'Smola White' inflorescences diameter decreased with $5.87 \mathrm{~cm}$, 'Arber' reported significant inhibition of inflorescences compared to control, and at 'Vienna White' high inhibition was only observed at PD treatment. MP treatments increased inflorescences diameter, with $1.1 \mathrm{~cm}$ compared to untreated plants.

\section{Discussion}

The results of this experiment showed that proper plant growth retardant may have a significant influence on the growth parameters of the Chrysanthemum to meet consumers' demands. In some studies, it was found that retardants do not affect the shape of the leaves, but the leaf area is reduced compared to non-treated plants $[17,20,44,45]$. However, other papers mentioned that the treatment effect could be variety-dependent, or influenced by the frequency of the application and/or other climatic conditions, which could affect the uptake of nutrients $[46,47]$. These results are also recorded in our experiment where in some cases the three varieties behaved differently. Moreover, in some experiments plant growth retardants are recommended to be used after one week of pinching $[48,49]$.

According to the present experiment it can be reported that plant growth retardants could increase or even inhibit the number of leaves; PD (Toprex SC) reported small de- 
creases, in contrast with the other three retardants (MP, PP, CC) where increases were observed in all varieties of Chrysanthemums. However, PD inhibited the number of leaves of the selected varieties, for chrysanthemum growers this is a negative effect, because leaves are an important part of the plant's compact look, this effect therefore reducing the plant quality and value. The highest number of leaves was observed at 'Smola White' under PP, CC, and MP treatments compared to the other two varieties. In a study conducted by Bidave and Munde [50] retardants beneficially decreased the plant height in Abelmoschus esculentus L., and minimized the days to open first flowers. Even in potato cultivation retardants are used for increasing production, which can cope with a reduced agronomic input [51].

The present experimental data clearly showed that retardants can influence in a positive way leaf length and width, in some cases by just a small percentage; this could help the inflorescence growth, and the leaf color became darker green. Furthermore, with the PD (Toprex SC) retardant the best results compared to control were obtained; with this treatment both mature and new leaves recorded the smallest diameters. Interestingly, in some cases the other three retardants used increased leaf length and width of both mature and new leaves. When comparing the varieties, it can be concluded that 'Vienna White' obtained the highest increases in length and width of leaves, on the other hand 'Smola White' reported the contrary. Similarly, to our study, other researchers also reported that retardants can reduce leaf appearance, however they can affect leaf color due to increased chlorophyll, and can reduce cell size in leaves [47,52].

It should be highlighted that all used plant growth regulators decreased the internodes length at all Chrysanthemum varieties, in some cases even by $50 \%$. However, the highest decrease was detected at plants under the PD treatment in all three varieties. Altogether it can be concluded that PD treatment has the highest effect on internodes length; these retardant plays and important role on blocking gibberellins biosynthesis, which is the key product for cell elongation, and because of this effect internodes length are inhibited. In other studies, it was also reported that plant growth regulators can inhibit internodes growth in Gossypium hirsutum L. [53,54], Bougainvillea [55], Vigna radiata L. [56] and on Zinnia elegans [57].

Like the other parameters, shoots length was influenced in a positive way by the retardants used in the experiment. The highest decrease was reported at the plants under PD treatment; in some cases, the shoot length was five times smaller than the control. PD retardant effect on shoot length could be an important data, because the purpose of the study was to obtain the mostly inhibiting retardant from the selected ones. When analyzing the shoot numbers, it can be concluded that the retardant did not affect these parameters at 'Arber' and 'Vienna White'; contrarily, inhibition was determined at 'Smola White' under the PD retardants, which could be a positive matter in plants cultivation, because the necessary nutrients could be transported to the inflorescences. Contrary to the shoot's length, 'Smola White' reported the highest number of shoots per plant. Similarly, to our study, some researchers reported that retardants did not affect shoot numbers [58,59].

In the floriculture cultivation, the most important part is the inflorescence of the plants. If the inflorescences are small, weak plants cannot be vended. However, under our experimental conditions, pedicel elongation decreased in all treatments compared to control, which has resulted in a smaller-compact plant; the varieties' pedicel elongation differed, which can be explained with the fact that this factor is variety-dependent. The highest pedicel elongation was detected at 'Vienna White'. Bud diameter of the treated plants in most of the cases was inhibited compared to control, only MP resulted in a similar bud diameter, which could be a good finding, even if chrysanthemums are under plant growth retardants, some of the applied treatments could influence morphological parameters, however they have no effect on bud diameter. Even if some growth parameters were affected by retardants, flowers quality and growth was not significantly affected. However, the MP, PP, CC retardants did not record significant increase in diameter: they recorded almost similar data to control. For chrysanthemum growers, the most important part of a potted 
plants is the inflorescence, if the flowers are small, weak and the plants are loose, they could even lose the consumers, also reported by other authors in Asiatic Lilium [60] Tagetes erecta L. [61,62], and Nerium oleander L. [63]. Plant growth retardants could even have a positive effect on flowering time, flower size, even vase life of Chrysanthemums [64-66]. On contrary, retardants being gibberellin inhibitors, and by this decreasing cell elongation, could reduce the growth and development of the plants, but even have negative influence on cultivated potted flowers, by decreasing/inhibiting the inflorescences [64,67].

\section{Conclusions}

The present study provides new experimental data on the comparison of three potted Chrysanthemum indicum L. varieties and the effect of four plant growth retardants on growth parameters. According to the results, it can be concluded that all selected retardants, PP, CC, MP, and PD inhibited chrysanthemum growth parameters. PD treatments obtained the highest inhibition effects of all measured morphological parameters, yet also reported a negative effect on the Chrysanthemums' inflorescences (smaller or even fewer inflorescences), which decreases the plants' value. MP affected the measured parameters numbers and growth, however did not inhibit inflorescences diameter. Altogether, it could be concluded that MP has the most desirable influence as plant growth retardant on chrysanthemums. Is important to mention that these recorded changes could also be variety-dependent factors. The work presented here strengthens the possibility of using retardants as plant growth inhibitors, but future experiments need to be conducted.

Author Contributions: Conceptualization, E.K. and A.B.; methodology, E.K.; formal analysis, E.K. and A.B.; resources, E.K. and A.B.; funding acquisition A.B.; writing-original draft preparation, E.K., Z.S.-V., J.B. and A.B.; writing-review and editing, E.K., Z.S.-V., J.B. and A.B.; supervision, E.K. and A.B. All authors have read and agreed to the published version of the manuscript.

Funding: This research received no external funding.

Institutional Review Board Statement: Not applicable.

Informed Consent Statement: Not applicable.

Data Availability Statement: Not applicable.

Acknowledgments: The author would like to express their special thanks to Ágota Szabó and Kázmér Kovács for the help with this research. Thanks to the support of University of Pecs from Hungary for this research.

Conflicts of Interest: The authors declare no conflict of interest.

\section{References}

1. Van Huylenbroeck, J. Status of floriculture in Europe. In Protocols for In Vitro Propagation of Ornamental Plants; Humana Press: Totowa, NJ, USA, 2010; pp. 365-376. [CrossRef]

2. Wani, M.A.; Nazki, I.T.; Din, A.; Iqbal, S.; Wani, S.A.; Khan, F.U. Floriculture sustainability initiative: The dawn of new era. In Sustainable Agriculture Reviews; Springer: Cham, Switzerland, 2018; Volume 27, pp. 91-127. [CrossRef]

3. Van Rijswick, C. World floriculture map 2015. In Gearing Up for Stronger Competition; Rabobank Industry Note: Utrecht, The Netherlands, 2015; p. 475.

4. Adebayo, I.A.; Pam, V.K.; Arsad, H.; Samian, M.R. The Global Floriculture Industry: Status and Future Prospects. In The Global Floriculture Industry; Apple Academic Press: New Jersey, NJ, USA, 2020; pp. 1-14.

5. Darras, A.I. Implementation of sustainable practices to ornamental plant cultivation worldwide: A critical review. Agronomy 2020, 10, 1570. [CrossRef]

6. Anderson, N.O. Chrysanthemum. In Flower Breeding and Genetics; Springer: Dordrecht, The Netherlands, 2007; pp. 389-437. [CrossRef]

7. Li, T.S.C. Chinese and Related North. American Herbs: Phytopharmacology and Therapeutic Values; CRC Press: Boca Raton, FL, USA, 2002; p. 598. [CrossRef]

8. Youssef, F.S.; Eid, S.Y.; Alshammari, E.; Ashour, M.L.; Wink, M.; El-Readi, M.Z. Chrysanthemum indicum and Chrysanthemum morifolium: Chemical Composition of Their Essential Oils and Their Potential Use as Natural Preservatives with Antimicrobial and Antioxidant Activities. Foods 2020, 9, 1460. [CrossRef] 
9. Cheng, W.; Li, J.; You, T.; Hu, C. Anti-inflammatory and immunomodulatory activities of the extracts from the inflorescence of Chrysanthemum indicum Linne. J. Ethnopharmacol. 2005, 101, 334-337. [CrossRef] [PubMed]

10. Shahrajabian, M.H.; Sun, W.; Zandi, P.; Cheng, Q. A review of Chrysanthemum, the eastern queen in traditional Chinese medicine with healing power in modern pharmaceutical sciences. Appl. Ecol. Environ. Res. 2019, 17, 13355-13369. [CrossRef]

11. Shao, Y.; Sun, Y.; Li, D.; Chen, Y. Chrysanthemum indicum L.: A Comprehensive Review of its Botany, Phytochemistry and Pharmacology. Am. J. Chin. Med. 2020, 48, 871-897. [CrossRef] [PubMed]

12. Cha, J.Y.; Nepali, S.; Lee, H.Y.; Hwang, S.W.; Choi, S.Y.; Yeon, J.M.; Song, B.J.; Kim, D.K.; Lee, Y.M. Chrysanthemum indicum L. ethanol extract reduces high-fat diet-induced obesity in mice. Exp. Ther. Med. 2018, 15, 5070-5076. [CrossRef] [PubMed]

13. Zhang, X.; Wu, J.Z.; Lin, Z.X.; Yuan, Q.J.; Li, Y.C.; Liang, J.L.; Zhan, J.Y.X.; Xie, Y.L.; Su, Z.R.; Liu, Y.H. Ameliorative effect of supercritical fluid extract of Chrysanthemum indicum Linnén against D-galactose induced brain and liver injury in senescent mice via suppression of oxidative stress, inflammation and apoptosis. J. Ethnopharmacol. 2019, 234, 44-56. [CrossRef]

14. Sangma, P.M.; Dhiman, S.R.; Thakur, P.; Gupta, Y.C. Effect of covering materials on off-season cut flower production in chrysanthemum (Dendrathema grandiflora). Indian J. Agric. Sci. 2016, 86, 522-526.

15. Souri, M.K.; Goodarzizadeh, S.; Ahmadi, M.; Hatamian, M. Characteristics of postharvest quality of chrysanthemum cut flowers under pretreatment with nitrogenous compounds. Acta Sci. Pol. Hortorum Cultus 2018, 17, 83-90. [CrossRef]

16. Sajjad, Y.; Jaskani, M.J.; Asif, M.; Qasim, M. Application of plant growth regulators in ornamental plants: A review. Pak. J. Agric. Sci. 2017, 54, 327-333. [CrossRef]

17. Choudhari, R.; Kulkarni, B.S.; Shiragur, M. Growth, flowering and quality of cut Chrysanthemum (Dendranthema grandiflora Tzevelev.) cv. Yellow Gold, as influenced by different growth regulators. Int. J. Chem. Stud. 2018, 6, 1458-1460.

18. Bons, H.K.; Kaur, M. Role of plant growth regulators in improving fruit set, quality and yield of fruit crops: A review. J. Hortic. Sci. Biotechnol. 2020, 95, 137-146. [CrossRef]

19. Rademacher, W. Growth retardants: Effects on gibberellin biosynthesis and other metabolic pathways. Annu. Rev. Plant Biol. 2000, 51, 501-531. [CrossRef]

20. Megersa, H.G.; Lemma, D.T.; Banjawu, D.T. Effects of plant growth retardants and pot sizes on the height of potting ornamental plants: A Short Review. J. Hortic. 2018, 5, 1-5. [CrossRef]

21. Fletcher, R.A.; Gilley, A.; Sankhla, N.; Davis, T.D. Triazoles as plant growth regulators and stress protectants. Hortic. Rev. 2000, 24, 55-138.

22. Rostami, S.; Azhdarpoor, A. The application of plant growth regulators to improve phytoremediation of contaminated soils: A review. Chemosphere 2019, 220, 818-827. [CrossRef] [PubMed]

23. Davis, T.D.; Curry, E.A.; Steffens, G.L. Chemical regulation of vegetative growth. Crit. Rev. Plant Sci. 1991, 10, 151-188. [CrossRef]

24. Desta, B.; Amare, G. Paclobutrazol as a plant growth regulator. Chem. Biol. Technol. Agric. 2021, 8, 1-15. [CrossRef]

25. Ahmade, E. Effect of Pinching and Paclobutrazol on Growth and Flowering of Garland Chrysanthemum (Chrysanthemum coronarium L.). SJAR 2019, 6, 409-419.

26. Elisheba, B.P.; Sudhagar, R. Growth manipulation in ornamental sunflower (Helianthus annuus) cv. Ring of Fire as a bedding plant. Crop Res. 2021, 56, 30-36.

27. Liang, F.B.; Yang, C.X.; Sui, L.L.; Xu, S.Z.; Yao, H.S.; Zhang, W.F. Flumetralin and dimethyl piperidinium chloride alter light distribution in cotton canopies by optimizing the spatial configuration of leaves and bolls. J. Integr. Agric. 2020, 19, 1777-1788. [CrossRef]

28. Cordeiro, C.F.D.S.; Santos, I.F.; Mello, P.R.D.; Echer, F.R. Cotton root growth response to mepiquat chloride application in early reproductive stages are cultivar dependent. Crop Sci. 2021, 61, 1-9. [CrossRef]

29. Polat, T.; Özer, H.; Öztürk, E.; Sefaoğlu, F. Effects of mepiquat chloride applications on non-oilseed sunflower. Turk. J. Agric. For. 2017, 41, 472-479. [CrossRef]

30. dos Santos, J.A.; Matsumoto, S.N.; Trazzi, P.A.; Ramos, P.A.S.; de Oliveira, L.S.; Campoe, O.C. Morphophysiological changes by mepiquat chloride application in Eucalyptus clones. Trees 2021, 35, 189-198. [CrossRef]

31. Nir, I.D.O.; Moshelion, M.; Weiss, D. The Arabidopsis GIBBERELLIN METHYL TRANSFERASE 1 suppresses gibberellin activity, reduces whole-plant transpiration and promotes drought tolerance in transgenic tomato. Plant Cell Environ. 2014, 37, 113-123. [CrossRef] [PubMed]

32. Nir, I.; Shohat, H.; Panizel, I.; Olszewski, N.; Aharoni, A.; Weiss, D. The tomato DELLA protein PROCERA acts in guard cells to promote stomatal closure. Plant Cell 2017, 29, 3186-3197. [CrossRef]

33. Kwok, I.M.Y.; Loeffler, R.T. The biochemical mode of action of some newer azole fungicides. Pestic. Sci. 1993, 39, 1-11. [CrossRef]

34. Hartwig, T.; Corvalan, C.; Best, N.B.; Budka, J.S.; Zhu, J.Y.; Choe, S.; Schulz, B. Propiconazole is a specific and accessible brassinosteroid (BR) biosynthesis inhibitor for Arabidopsis and maize. PLoS ONE 2012, 7, e36625. [CrossRef]

35. Bajguz, A.; Hayat, S. Effects of brassinosteroids on the plant responses to environmental stresses. Plant Physiol. Biochem. 2009, 47, 1-8. [CrossRef] [PubMed]

36. Nolan, T.M.; Vukašinović, N.; Liu, D.; Russinova, E.; Yin, Y. Brassinosteroids: Multidimensional regulators of plant growth, development, and stress responses. Plant Cell 2020, 32, 295-318. [CrossRef]

37. Zhang, M.; Yang, J.; Pan, H.; Pearson, B.J. Dwarfing Effects of Chlormequat Chloride and Uniconazole on Potted Baby Primrose. HortTechnology 2020, 30, 536-543. [CrossRef] 
38. Shevchuk, O.A.; Kravets, O.O.; Shevchuk, V.V.; Khodanitska, O.O.; Tkachuk, O.O.; Golunova, L.A.; Polyvanyi, S.V.; Knyazyuk, O.V.; Zavalnyuk, O.L. Features of leaf mesostructure organization under plant growth regulators treatment on broad bean plants. Mod. Phytomorphol. 2020, 14, 104-106.

39. Singh, J.; Kumar, J.; Nigam, R.; Singh, R.; Kumar, A.; Singh, H. Influence of growth retardant and inorganic fertilizers on vegetative growth of Chrysanthemum (Dendranthema grandiflora Ramat). Int. J. Agric. Inv. 2018, 3, 25-33. [CrossRef]

40. Burrows, G.E.; Boag, T.S.; Stewart, W.P. Changes in leaf, stem, and root anatomy of Chrysanthemum cv. Lillian Hoek following paclobutrazol application. J. Plant Growth Regul. 1992, 11, 189-194. [CrossRef]

41. Karlović, K.; Vršek, I.; Šindrak, Z.; Židovec, V. Influence of growth regulators on the height and number of inflorescence shoots in the Chrysanthemum cultivar 'Revert'. Agric. Conspec. Sci. 2004, 69, 63-66.

42. El-Sheibany, O.M.; El-Malki, N.A.; Barras-Ali, A. Effect of application of growth retardant ALAR on some foliage characters of local cultivar of Chrysanthemum. J. Sci. Appl. 2007, 1, 15-20.

43. Zakrzewski, P.; Anita Schroeter-Zakrzewska, A. Growth retardants in the cultivation of Chrysanthemum X grandiflorum (Raman.) Kitam.'Leticia Time Yellow'. Folia Hortic. 2011, 23, 139-143. [CrossRef]

44. El-Malki, N.A.; Barras-Ali, A. Effect of Growth Retardant ALARR on Some Anatomical and Chemical Changes in local Cultivar of Chrysanthemum morifolium. SJUB 2015, 1, 64.

45. Suman, M.; Sangma, P.D.; Meghawal, D.R.; Sahu, O.P. Effect of plant growth regulators on fruit crops. J. Pharmacogn. Phytochem. 2017, 6, 331-337.

46. Qureshi, I.A.; Gulzar, S.; Dar, A.R.; Rehman, R.U.; Tahir, I. Effect of growth retardants on the growth and flowering of Chrysanthemum morifolium cv. Flirt. Indian J. Agric. Res. 2018, 52, 319-322. [CrossRef]

47. Kumar, S.; Sujin, G.S.; Arivazhagan, E.; Sudhagar, R.; Muraleedharan, A. Studies on Influence of Growth Retardants on Flower Crops. Pract. Res. 2020, 2, 51.

48. Abrol, A.; Dhiman, S.R.; Sharma, P.; Sharma, M. Effect of growth regulators on potted chrysanthemum under different photoperiodic conditions. J. Hill Agric. 2018, 9, 165-170. [CrossRef]

49. Abrol, A.; Dhiman, S.R.; Sharma, P. Effect of cultivars, growth regulators and photoperiods on production of potted chrysanthemum, Dendranthema grandiflora Tzvelev. Int. J. Farm Sci. 2018, 8, 66-72. [CrossRef]

50. Bidave, S.R.; Munde, G.R. Effect of growth retardants on vegetative and flowering characters of okra (Abelmoschus Esculentus L.) CV. PBN-OK-1. J. Life Sci. 2020, 17, 59-62.

51. Ellis, G.D.; Knowles, L.O.; Knowles, N.R. Increasing the Production Efficiency of Potato with Plant Growth Retardants. Am. J. Potato Res. 2020, 97, 88-101. [CrossRef]

52. Youssef, A.S.M. Effect of Some Growth Retardants and Pinching on Growth, Flowering and Chemical Composition of Tabernaemontana Coronaria Plant. Ann. Agric. Sci. 2020, 58, 1023-1038. [CrossRef]

53. Wang, L.; Yin, Y.; Wang, L.F.; Wang, M.; Zhao, M.; Tian, Y.; Li, Y.F. Transcriptome profiling of the elongating internode of cotton (Gossypium hirsutum L.) seedlings in response to mepiquat chloride. Front. Plant Sci. 2020, 10, 1751. [CrossRef] [PubMed]

54. Wang, L.; Yin, Y.; Jing, X.; Wang, M.; Zhao, M.; Yu, J.; Qiu, Z.; Li, Y.F. Profiling of MicroRNAs Involved in Mepiquat ChlorideMediated Inhibition of Internode Elongation in Cotton (Gossypium hirsutum L.) Seedlings. Front. Plant Sci. 2021, $12,255$. [CrossRef]

55. Rohith, R. Standardization of Growth Retardants for Production of Potted Bougainvillea. Chem. Sci. Rev. Lett. 2021, 10, 214-220. [CrossRef]

56. Singh, G.; Kumar, K.; Chahal, H.S. Effect of Mepiquat chloride and detopping on growth and production of green gram (Vigna radiata L. Wilczek). Environ. Conserv. J. 2020, 21, 85-88. [CrossRef]

57. Pinto, A.C.R.; Rodrigues, T.D.J.D.; Leite, I.C.; Barbosa, J.C. Growth retardants on development and ornamental quality of potted 'Lilliput' Zinnia elegans Jacq. Sci. Agric. 2005, 62, 337-345. [CrossRef]

58. Kumari, S. Effect of growth retardant (CCC) and growth promoter (6-FAP) on seedling growth and chlorophyll content of Coleoptile leaves in pearl millet (Pennisetum glaucum L.) under moisture stress. Int. J. Curr. Microbiol. Appl. Sci. 2017, 6, $2522-2529$. [CrossRef]

59. Singh, G.; Kumar, K.; Singh, A. Effect of growth retardant and detopping on growth and yield of summer mungbean (Vigna radiata L. Wilczek) under vertisols of Punjab. J. Food Legum. 2020, 33, 64-66.

60. Malik, K.M.; Wani, A.H.; Nazki, I.T. Effect of growth retardants on growth, flowering and bulb yield of Asiatic Lilium. Int. J. Sci. Res. 2021, 11, 448-452. [CrossRef]

61. Sunayana, S.; Manjusha, A.M.; Rajagopalan, A.; Madala, A. Effect of growth retardants (Alar and Cycocel) on flower yield and carotenoid content in African marigold (Tagetes erecta L.) varieties. J. Trop. Agric. 2018, 55, 205-208.

62. Sahu, M.K.; Tirkey, T.; Tamrakar, S.K.; Tiwari, S.P.; Shukla, N.; Varma, L.S.; Shankar, D. Effect of plant growth retardants and their time of application on flower quality attributes of African marigold (Tagetes erecta L.). J. Pharm. Innov. 2021, 10, 932-936.

63. Rajiv, G. Effect of Plant Growth Retardants on the Growth and Flowering of Nerium (Nerium Oleander L.) Cv. Red. Chem. Sci. Rev. Lett. 2018, 7, 875-879.

64. Alhajhoj, M.R. Effects of Foliar Application of Plant Growth Regulators on Growth and Flowering Characteristics of Chrysanthemum CV. Paintball. Pak. J. Life Soc. Sci. 2017, 15, 114-119.

65. Vineeta, P.; Sankar, M.V.; Anuj, K.; Singh, O.P. Effect of plant growth regulators on growth, flowering and flower quality of chrysanthemum (Dendranthema grandiflora Tzvelev). Green Farming 2018, 9, 173-175. 
66. Sahu, J.K.; Tamrakar, S.K.; Lakpale ${ }^{1}$, R.; Tirkey, T. Effect of planting geometry and plant growth regulators on growth and flowering of chrysanthemum. Progress. Hortic. 2021, 53, 105-108. [CrossRef]

67. Vaghasia, M.; Polara, N.D. Effect of plant growth retardants on growth, flowering and yield of chrysanthemum (Chrysanthemum morifolium Ramat.) cv. IIHR-6. MJMBR 2016, 3, 99-104. [CrossRef] 